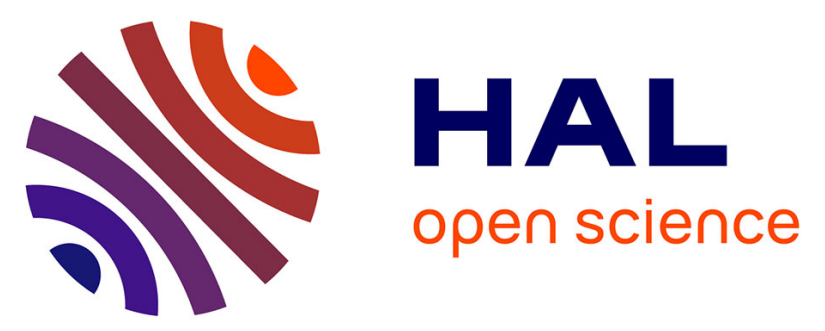

\title{
Temperature but not moisture response of germination shows phylogenetic constraints while both interact with seed mass and lifespan
}

Fabien Arène, Laurence Affre, Aggeliki Doxa, Arne Saatkamp

\section{To cite this version:}

Fabien Arène, Laurence Affre, Aggeliki Doxa, Arne Saatkamp. Temperature but not moisture response of germination shows phylogenetic constraints while both interact with seed mass and lifespan. Seed Science Research, 2017, 27 (02), pp.110 - 120. 10.1017/S0960258517000083 . hal-01533511

\author{
HAL Id: hal-01533511 \\ https://hal.science/hal-01533511
}

Submitted on 7 May 2018

HAL is a multi-disciplinary open access archive for the deposit and dissemination of scientific research documents, whether they are published or not. The documents may come from teaching and research institutions in France or abroad, or from public or private research centers.
L'archive ouverte pluridisciplinaire HAL, est destinée au dépôt et à la diffusion de documents scientifiques de niveau recherche, publiés ou non, émanant des établissements d'enseignement et de recherche français ou étrangers, des laboratoires publics ou privés. 


\section{Temperature but not moisture response of germination shows phylogenetic constraints while both interact with seed mass and lifespan}

Fabien Arène, Laurence Affre, Aggeliki Doxa and Arne Saatkamp*

Institut Méditerranéen de Biodiversité et d'Ecologie (IMBE), Aix Marseille Université, CNRS, IRD, Université Avignon, Faculté St-Jérôme Case 421, 13397 Marseille cedex 20, France

* Correspondence Email: arne.saatkamp@imbe.fr

\section{Abstract}

Understanding how plant traits interact with climate to determine plant niches is decisive for predicting climate change impacts. While lifespan and seed size modify the importance of germination timing, germination traits such as base temperature and base water potential directly translate climatic conditions into germination timing, impacting performance in later life stages. Yet we do not know how base temperature, base water potential, seed mass, lifespan and climate are related. We tested the relationships between base temperature and base water potential for germination, seed size and lifespan while controlling for bioclimatic regions. We also quantified the phylogenetic signal in germination traits and seed size using Pagel's $\lambda$. We used a worldwide data set of germination responses to temperature and moisture, seed size and lifespan of 240 seed plants from 49 families. Both germination temperature and moisture are negatively related to seed size. Annual plants show a negative relation between seed size and base water potential, whereas perennials display a negative relation between base temperature and seed mass. Pagel's $\lambda$ highlighted the slow evolution of base temperature for germination, comparable to seed mass while base water potential was revealed to be labile. In the future, base water potential and seed mass can be used when moisture niches of plants are to be predicted. Lifespan, seed size and base temperature should be taken into account when analysing thermal limits of species distributions.

Keywords: base temperature, base water potential, germination traits, hydrotime, lifespan, phylogenetic signal, seed size, seed-plant, thermal time 


\section{Introduction}

Understanding how changing climate influences earth ecosystems depends critically on how plants respond to gradients of temperature and moisture (Parmesan et al., 2005; Bykova et al., 2012; Silvertown et al., 2015). This puts the question of which adaptive traits of seed plants correspond to climatic niches at the core of functional ecology (Jump and Penuelas, 2005; McGill et al., 2006; Chuine, 2010; Gallagher et al., 2010). If we want to predict plant responses to changing temperature and moisture, we need to know how the interaction of traits and the environment translates into realized niches (García-Baquero et al., 2015; Silvertown et al., 2015). The underlying trade-offs and the evolutionary constraints of traits related to climatic niches have been studied (Wright et al., 2004; Evans et al., 2005; Donoghue and Edwards, 2014), but the implication of regeneration traits in relation to climatic features is little explored despite its potentially decisive role in successful regeneration (Holt and Chesson, 2014; Huang et al., 2016).

Whereas traits of adult plants related to climate are studied on a worldwide scale (Wright et al., 2004; Chave et al., 2009; Sack et al., 2013), our understanding of the link between reproductive traits and climate is more limited - with the exception of seed size (Moles et al., 2007). This contrasts with findings that show adaptations of seeds and seedlings determining range limits, community assembly, and population dynamics (Morin et al., 2007; Poorter, 2007; Donohue et al., 2010; Huang et al., 2016; Jiménez-Alfaro et al., 2016). Harper et al. (1965) and Grubb (1977) demonstrated how important 'regeneration niches' and 'safe sites' are by showing that biotic and abiotic environments of plants during germination, establishment of seedlings and onward growth determine position and success of adults. Whereas studies focusing on 'survival niche' of seedlings revealed the importance of climatic niches (Leishman and Westoby, 1994; Bykova et al., 2012;), the role of adaptations and trade-offs at the germination process with climate has received comparatively little attention (Kruk et al., 2006; Holt and Chesson, 2014; Huang et al., 2016).

In contrast to dormancy, which gives larger seasonal timing of germination (Donohue, 2002; Baskin and Baskin, 2014), germination is a short-term process transforming seeds into seedlings that are more vulnerable to environmental hazards (Sarukhan and Harper, 1973; Harper, 1977; Mazer, 1989). Germination timing influences the adaptation to environmental conditions that individuals will experience for long periods afterwards (Donohue, 2002). Hence the regeneration niche determines the survival niche of seedlings and even trait contrasts in adults (Poorter, 2007). This further underlines the importance of carrying out studies on the links between germination requirements, seed traits and the interaction with adult plant traits.

Germination of seeds depends primarily on climatic variables such as temperature and moisture conditions in the seed bed (Kruk et al., 2006; Saatkamp et al., 2011a; Baskin and Baskin, 2014; 
Huang et al., 2016). The latter are particularly crucial germination cues as they also influence later growth (Poorter and Nagel, 2000; Rustad et al., 2001). Germination timing of non-dormant seeds with the environment can be modelled effectively as a function of time passed above threshold values such as base temperature $\left(T_{b}\right)$ and base water potential $\left(\Psi_{b}\right)$ (Steinmaus et al., 2000; Bradford, 2002; Trudgill et al., 2005). Hydrothermal time models (HTT models) rely on $\mathrm{T}_{\mathrm{b}}$ and $\Psi_{\mathrm{b}}$ and have previously been used to model crop emergence and germination of agricultural weeds from soil seed banks (Bradford, 2002; Kruk et al., 2006) and according to recent analysis also play an important role in persistence in the soil seed bank (Saatkamp et al., 2011b). Parameters of germination models are of growing interest in comparative germination ecology as they appear to be specific adaptations of plants to their environment (Allen et al., 2000; Huang et al., 2016). Although the fundamental functional and comparative value of germination traits has been identified, little is known about the relationships between germination traits such as $T_{b}, \Psi_{b}$ and other seed traits, such as seed size.

Seed size has notably been related to light and moisture conditions that seedlings experience during establishment (Salisbury, 1942; Foster and Janson, 1985; Metcalfe and Grubb, 1995). Seed size is related to fitness of seedlings, as individuals producing larger seeds benefit from better seedling establishment and higher seedling survival in relation to smaller seeds that are more numerous (Lloret et al., 1999; Moles et al., 2004; Moles and Westoby, 2004). Beyond such advantages, greater seed size has been suggested as an adaptive trait in the reduction of between-year variation in mortality in the framework of bet-hedging when rainfall varies from year to year (Venable and Brown, 1988; Leishman and Westoby, 1994; Metz et al., 2010). Seed size has also been linked to moisture niches of plants (Baker, 1972), notably by conferring a higher rate of survival of large seedlings under drought (Leishman and Westoby, 1994; Lloret et al., 1999). Taken together, this suggests that larger seeded plants can successfully reproduce in drier environments or environments with unpredictable drought compared with small seeds which would need more moisture. Thus large seeds should germinate at lower soil water potentials, and hence lower base water potentials $\left(\Psi_{b}\right)$ than small seeds. In addition, if risk reduction is an important selective pressure for the evolution of seed size, then perennials should exhibit a stronger correlation between base water potential $\Psi_{b}$ and seed size than annual plants, because perennials can survive as adults for several reproductive seasons and produce seed in other years. Among the few studies that have explored the link between germination niche and seed traits, Daws et al. (2008) illustrated for a guild of tropical pioneer trees that large seeds can germinate in drier conditions than small seeds by having lower base water potentials $\left(\Psi_{b}\right)$, as a consequence of their higher drought resistance. However, for other bioclimatic zones, such as nemoral (temperate humid regions), Mediterranean and dry tropics, the relationships between germination traits such as base water potential and base temperature, seed size and lifespan have not yet been explored. 
Moreover, beyond the ecological significance, information on the evolution of thermal and hydric aspects of the germination niche remains scarce. Some authors (Donohue et al., 2005) have shown that a shift from autumn to spring germination due to different levels of dormancy can undergo rapid local adaptation. However, studies on dormancy classes highlighted that these traits display a strong phylogenetic signal (Baskin et al., 2000; Forbis et al., 2002; Finch-Savage and Leubner-Metzger, 2006; Baskin and Baskin, 2014). Across the entire seed plant phylogeny, climatic niche evolution shows inertia due to features inherited from ancestors (Prinzing et al., 2001; Qian and Ricklefs, 2004; Schnitzler et al., 2012), more commonly referred to as phylogenetic signal (Losos, 2008). Unlike realized adult niche, the evolution of thermal and hydric aspects of germination niche has been less studied, with the notable exception of Rosbakh and Poschlod (2014) who found no clear phylogenetic signal for their initial temperature (i.e. the minimum temperature allowing $5 \%$ germination of a seed lot) which calls for a broader evaluation of phylogenetic conservatism for germination traits. In contrast, several analyses of the evolution of seed size (Leishman et al., 2000; Moles et al., 2005) revealed a strong phylogenetic signal. Altogether, these contrasting findings raise the question whether germination traits show a phylogenetic signal and to what extent they are related to seed size and other fundamental plant traits.

In order to address the functional link between germination traits and seed mass, we asked four questions.

(i) Do germination traits show a strong phylogenetic signal, and how does it compare with the phylogenetic signal of seed mass?

(ii) Are the germination base temperature and base water potential negatively related to seed mass?

(iii) What is the relationship between germination traits $\left(T_{b}\right.$ and $\left.\Psi_{b}\right)$ and seed mass, and does this relationship differ between annual and perennial plants?

(iv) How do bioclimatic zones influence the relationships between germination traits, seed size and lifespan?

To answer these questions, we compiled a data set on base temperature $T_{b}$ and base water potential $\Psi_{\mathrm{b}}$, based on published germination experiments under controlled conditions of seed plants, as well as information on seed mass, lifespan and distribution in bioclimatic zones. 


\section{Materials and methods}

\section{Base temperatures, base water potentials and seed masses}

We performed a literature search on studies reporting experimental data on hydrotime and thermal time models and found 82 publications, including the important database recently published by Dürr et al. (2015). We searched for studies using the keyword 'germination', combined with one of 'temperature, thermal time, base temperature, water potential, moisture, base water potential, hydrotime, hydrothermal time, model'; we accessed Google Scholar and ScienceDirect databases until June 2015, and our search covers data until that date. This resulted in 201 species for $T_{b}$ and 102 species for $\Psi_{b}$, and a total of 240 species were taken into account in our study. The number of species was necessarily limited because of the high number of experimental conditions and replicates needed for estimating $T_{b}$ and $\Psi_{b}$ and the need for having complete trait sets for comparison among traits. Nevertheless, our data covered 49 families and all major clades of seed plants, several species-rich biomes and plants with native ranges in contrasting rainfall and temperature conditions. There is, however, a lack of data for plants from arctic-alpine habitats, tropics, tropical mountains and extreme deserts. In most published work, authors studied thermal and hydric time models separately, which explains the difference in sample size between $T_{b}$ and $\Psi_{\mathrm{b}}$. The HTT model is a population-based model describing the germination course of a seed lot in terms of temperature and moisture. Among the possible parameters of HTT models, here we only use base temperatures $\left(T_{b}\right)$ and base water potentials $\left(\Psi_{b}\right)$, above which thermal time and hydric time accumulates until germination can occur. Although we present here the thermal time and hydrotime models separately, temperature and moisture parameters can be modelled together in HTT models (Bradford, 2002). However, base water potential refers to a fraction of a seed lot, conventionally $50 \%$, and $\Psi_{\text {b50 }}$ is the minimum water potential necessary to promote the germination of $50 \%$ of a seed lot. For convenience, in this paper we refer to the base water potential of the $50 \%$ fraction $\left(\Psi_{b 50}\right)$ simply as the base water potential $\left(\Psi_{b}\right)$. At sub-optimal temperatures, the $\Psi_{b}$ does not vary as a function of temperature; however, when temperatures rise above the optimal temperature the $\Psi_{\mathrm{b}}$ increases with temperature and finally reaches a value of 0 $\mathrm{MPa}$ (free water) for all seed fractions, which prevents germination of seeds. Both $T_{b}$ and $\Psi_{b}$ can change according to dormancy status of the seed lot (Batlla and Benech-Arnold, 2003; Bair et al., 2006). In both cases, dormancy breaking tends to lower base temperatures (Batlla and BenechArnold, 2003) and base water potentials (Bair et al., 2006) for germination. To quantify the influence of dormancy on our results, we therefore ran two analyses, one with mean and the other with the minimum base temperatures for germination when several different entries per species were available. However, Thompson (1970a,b) showed that fresh seed lots showed more contrasted germination niches in terms of minimum and maximum temperatures for germination 
compared with seed lots for which dormancy was alleviated by dry storage. We excluded from our analysis the data from studies that estimated base water potentials indirectly, by comparison of species under greenhouse or field conditions and/or by holding other thermal or hydrotime parameters constant, without using different levels of base water potentials, notably the important data in Köchy and Tielbörger (2007). We therefore expect that residual dormancy does not change the results in terms of phylogenetic signal or trait-trait relationships.

We extracted seed masses for the 240 species of our study from the Kew Garden database (Royal Botanic Gardens, Kew, 2014) and obtained missing values from the LEDA seed trait database (Kleyer et al., 2008).

Finally, to assess the potential differences in the germination behaviour as a function of adult longevity, we distinguished perennial (108 and 46 for $T_{b}$ and $\Psi_{b}$, respectively) from annual plants (93 and 56 for $T_{b}$ and $\Psi_{b}$, respectively). We also attributed each plant to a major climatic type: nemoral, Mediterranean, dry tropic and wet tropic, according to their distribution given in regional floras of Europe (Tutin et al., 1964) and China (Flora of China: http://flora.huh.harvard.edu/china/). We excluded from our analyses the only representative from the arctic-alpine biome, Dryas octopetala (Rosaceae).

\section{Seed plant phylogeny}

We compiled a phylogeny using the dated, ultrametric supertree for 4685 European vascular plants based on 518 recent molecular phylogenies by Durka and Michalski (2012). We first completed this tree for the 89 species in our data set that were missing in the tree following the methods of Durka and Michalski (2012), based on molecular phylogenies. We then reduced this tree to the 240 species in our data set belonging to 49 families (Supplementary Figure S1). Phylogenies were pruned in each analysis to a more restricted species set using the comparative data algorithm implemented in the caper package (Orme, 2013).

\section{Phylogenetic signal and evolution of climatic niche and seed mass}

We used Pagel's $\lambda$ and maximum likelihood (Pagel, 1999; Freckleton et al., 2002) to test whether more closely related species across the seed plant phylogeny are more likely to share similar features of base temperature, base water potential and seed mass. Pagel's 
$\lambda$ uses an explicit evolutionary approach which indicates the influence of phylogeny in the between-species covariance for a given trait. The $\lambda$ parameter varies between 0 , indicating that the evolution of the trait is independent of phylogeny, without phylogenetic signal, and 1, trait evolution following Brownian motion. Any value of $\lambda$ significantly higher than zero indicates phylogenetic signal approaching Brownian motion to a different degree.

\section{Germination traits and seed mass links}

We applied phylogenetic generalized least square (PGLS) models (Felsenstein, 1985; Grafen, 1989) to study the relation between germination traits and seed mass when residual errors of the regressions were not independent between observations, as suggested by Revell (2010); otherwise, we used an ordinary least square (OLS) model. We used PGLS to study the relationship between $T_{b}$ and seed mass in the whole data set and to distinguish annual from perennial plants. We also used PGLS to study the relation between germination traits ( $T_{b}$ and $\Psi_{b}$ ) and seed mass in the dry tropic and nemoral data subset. All other relations showing any conditions cited above were tested using OLS. We computed all statistical analyses using R Core Team software (2014).

\section{Results}

\section{Germination traits and seed mass evolution}

Our results showed a strong phylogenetic signal for seed mass with a $\lambda$ significantly different from zero and equal to unity $(\lambda=1, P<0.001)$. The germination traits $T_{b}$ and $\Psi_{b}$ displayed contrasting results. Whereas we found a strong phylogenetic signal for base temperature $(\lambda=0.96, P<0.001)$, we detected no phylogenetic signal for base water potential $(\lambda=0.35, P>0.1)$. We present values of seed mass, $T_{b}$ and $\Psi_{b}$ mapped on the phylogeny (Supplementary Figures S2, S3 and S4). The phylogenetic signal remained strong and significant when we used minimum values for base temperature $(\lambda=0.95, P<0.001)$. When we replaced mean by minimum values for base water potential, still no phylogenetic signal was detected, with minimum instead of mean values $(\lambda<$ $0.01, P>0.1$ ). 
Whereas we found a weak positive relation between base temperature and seed mass using ordinary least squares $\left(n=230, R^{2}=0.05\right.$, slope $\left.=0.8, P<0.001\right)$, this relationship was not significant in phylogenetic least squares regression $\left(n=192, R^{2}<0.01\right.$, slope $=-0.11, P=0.697$, maximum-likelihood adjusted $\lambda=0.931$ ).

In contrast, we found a weak but significant relationship between base water potential and seed mass $\left(n=93, R^{2}=0.039\right.$, slope $\left.=-0.14, P<0.05\right)$.

No significant relationship was found between base temperature and seed mass in either the annual (Fig. 1A) or perennial data subset (Fig. 1B). We found a significant negative relationship between $\Psi_{\mathrm{b}}$ and seed mass only in the annual data subset (Fig. 1C), while perennials did not show any relationship (Fig. 1D).

Separate analyses for the four biomes showed a negative relationship between $T_{b}$ and seed mass in the nemoral $\left(n=112, R^{2}=0.093\right.$, slope $\left.=-1.28, P<0.01\right)$ and Mediterranean biomes $(n=50$, $R^{2}=0.22$, slope $=-2.18, P<0.001$ ) but not in dry or wet tropics. In contrast, we found a positive relationship between $T_{b}$ and seed mass for the dry tropic biome $\left(n=11, R^{2}=0.55\right.$, slope $=3.17, P$ $<0.01)$ and no relationship in the wet tropic data set. The regression analyses between $\Psi_{\mathrm{b}}$ and seed mass revealed a significant negative relationship in nemoral $\left(N=36, R^{2}=0.114\right.$, slope $=-$ $0.201, P<0.05)$ and Mediterranean biomes $\left(N=34, R^{2}=0.16\right.$, slope $\left.=-0.302, P<0.05\right)$ but no significant relationship for data from dry or wet tropics.

When we separated annual from perennial plants within biomes, our analyses showed significant negative relationship between $T_{b}$ and seed mass only for perennial plants from the nemoral biome $\left(\mathrm{N}=70, \mathrm{R}^{2}=0.16\right.$, slope $\left.=-1.43, \mathrm{P}<0.001\right)$ and annual plants from the Mediterranean species $(\mathrm{N}$ $=35, R^{2}=0.26$, slope $\left.=-2.06, P<0.01\right)$ but a positive relationship for perennials from the dry tropics $\left(N=8, R^{2}=0.54\right.$, slope $\left.=3.589, P<0.05\right)$. The other combinations of lifespan $x$ biome types had few data points and yielded no significant test. 


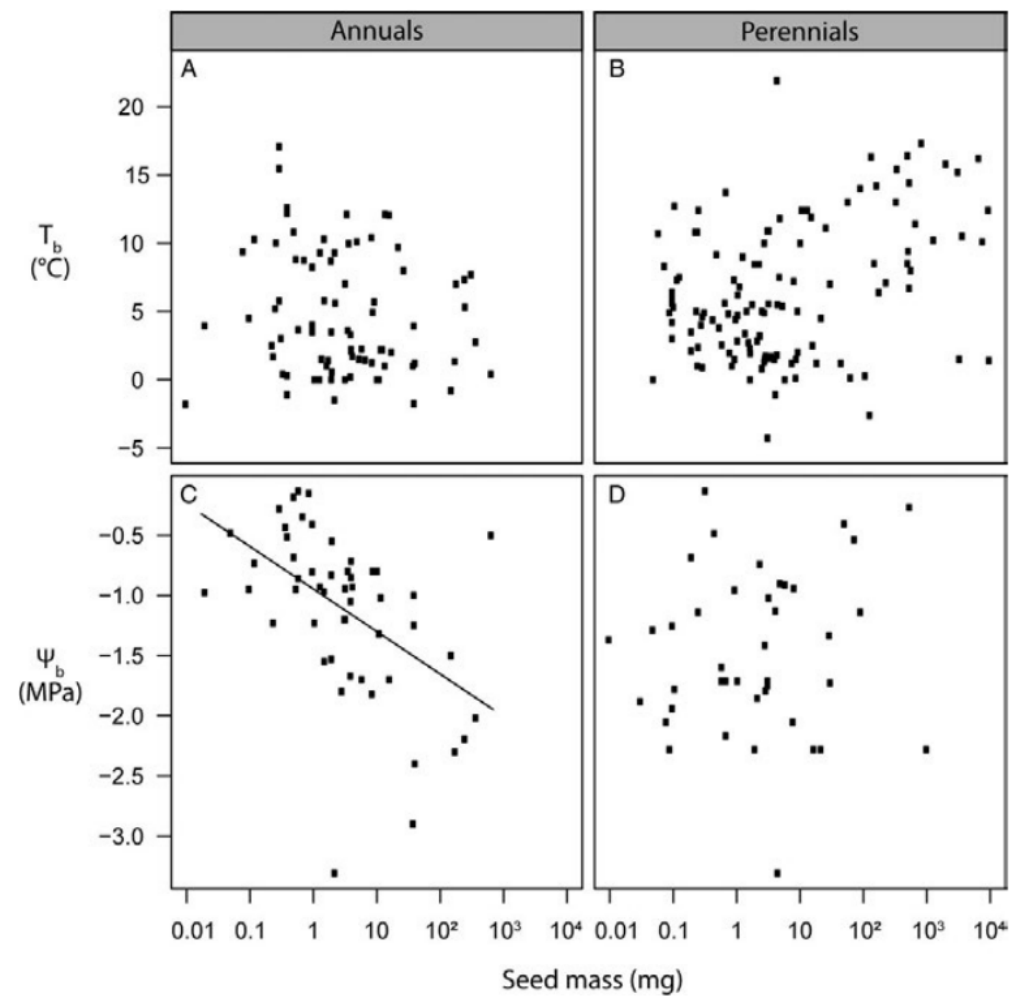

Figure 1. Phylogenetic least square regression of the base temperature $\left(T_{b}\right)$ on seed mass $\left(\log _{10}\right.$ transformed); (A) across the annual data subset $(n=82$; not significant, n.s.) and (B) across perennial data subset $(n=121 ; n$.s. $)$. Ordinary least square regression of the base water potential $\left(\Psi_{b}\right)$ on seed mass $\left(\log _{10}\right.$ transformed); (C) across the annual data subset $\left(n=52 ; R^{2}=0.23 ;\right.$ slope $\left.=0.36 ; P<0.001\right)$ and (D) across perennial data subset $(n=41$; n.s. $)$.

The regression analyses between $\Psi_{\mathrm{b}}$ and seed mass revealed a significant negative relationship for Mediterranean annuals $\left(n=26, R^{2}=0.26\right.$, slope $\left.=-0.37, P<0.01\right)$. There was no relationship for nemoral and tropical plants. None of the regression results related above changed when we used minimum instead of mean values for $T_{b}$ and $\Psi_{b}$ (see Supplementary Material).

\section{Discussion}

\section{Evolution of base temperature and base water potential}

Here, we provide first evidence of a phylogenetic signal in base temperature, a key temperaturerelated germination trait, in a worldwide data set for seed plants. This suggests that germination traits related to temperature are more phylogenetically conserved than base water potential and show a phylogenetic signal as strong as seed mass. 
The strong phylogenetic signal of base temperature for germination may be the result of a multitude of different enzymatic processes involved in germination itself (Holdsworth et al., 2008), each based on many different proteins having their own thermal characteristics (Daniel and Danson, 2010). Thermal characteristics of enzymatic processes may receive contrasting selection pressures, since several of the involved proteins are also expressed in later life stages (Schmid et al., 2005) and are thus part of a plant's general adaptation to temperature. Our findings develop and extend data presented by Rosbakh and Poschlod (2014), who found no phylogenetic signal using Blomberg's K statistic for 50 species but found significant differences among some plant families for 'initial temperature', i.e. the lowest temperature at which they observed germination. Our results go beyond previous findings since we used base temperature, $T_{b}$, which is known to be a fundamental physiological trait synthesizing the response of germination to temperature (Trudgill et al., 2005). In addition, we used Pagel's $\lambda$ to quantify phylogenetic signal, which is more efficient than Blomberg's K (Münkemüller et al., 2012) in the detection of the phylogenetic signal. It has been shown that $\mathrm{T}_{\mathrm{b}}$ and $\Psi_{\mathrm{b}}$ change according to dormancy status of the seed lot (Batlla and Benech-Arnold, 2003; Bair et al., 2006), and one might argue that this impedes their use in comparative studies. However, studies on germination in Silene (Thompson, 1970a,b) showed that fresh seed lots showed more contrasted germination niches in terms of minimum and maximum temperatures for germination compared with seed lots in which dormancy was alleviated by dry storage. Comparable analysis of traits brings important understanding of plant function although they are variable, e.g. specific leaf area also shows large variation in values according to water status of leaves, plant growing conditions, but which do not change the relative ranking of species (Roche et al., 2004). Moreover, the strong phylogenetic signal across a large data set indicates that base temperature for germination has a species-specific value that varies in a small range, and our data indicate that closely related species can be a predictor of that value.

The greater evolutionary lability of $\Psi_{b}$ can be understood as a consequence of more rapid local adaptation in response to a rapid shift in moisture conditions of the environment and its high spatial variability. Although there are no data on rapid evolution and local adaptation for $\Psi_{\mathrm{b}}$ itself, studies on other drought resistance traits show their high heritability and rapid evolution (Thomas, 1990). Moreover, Agrawal et al. (2013) have shown rapid evolution of life history traits in the evening primrose Oenothera biennis (Onagraceae), partly due to genotypic variation in seed germination. Thus it seems possible that $\Psi_{b}$ varies greatly among populations of closely related species due to rapid evolution, overriding a long evolutionary history. 


\section{Base temperature and seed mass}

Here, we provide evidence that the base temperature $T_{b}$ increases weakly with seed mass across all angiosperms, but this pattern appears to be related to larger seed mass of tropical compared with temperate clades and becomes non-significant when phylogeny is taken into account. When separating these data for different biomes, base temperature decreases with seed mass in seasonal climates, this relation being stronger for perennials than for annual plants in the nemoral biome, and stronger for annuals than for perennial plants in the Mediterranean biome. A plausible explanation for a stronger effect for perennials is that perennial plants cannot escape extreme temperatures such as frost since they usually must grow for at least two growing seasons before reproduction, spanning times of frost or drought, which annuals can overcome in the soil seed bank. A higher base water potential of perennial plants may contribute to later germination and this leaves time for potential dispersal to a wetter site. The necessary important short-distance dispersal in the seed bank has been quantified by Olano et al. (2012). This idea is also sustained by research showing that seedlings in their first year are highly vulnerable to climatic hazards (Lodge and Whalley, 1981). Germination timing should thus coincide with seasons that optimize survival of seedlings to following climatic hazards (Baskin and Baskin, 2014). This is in line with the observation that seedlings of perennials allocate most seed resources to survival in contrast to annuals, which allocate more to growth and reproduction (Primack, 1979; Garnier, 1992) and invest more in extensive root systems (Roumet et al., 2006). Since seedlings from larger seeds also survive frost better (Aizen and Woodcock, 1996), it becomes plausible that adaptation to different temperatures is influenced by seed size.

In our data set for perennials, the lower base temperature of large compared with small seeds suggests that they can germinate at colder temperatures than small seeds. Germination at colder temperatures exposes seedlings necessarily to colder initial environments or even to higher risks of frost. However, some seeds of winter annuals can be very small (e.g. Carophyllaceae, Brassicaceae) and seedlings live and grow even under snow (Baskin and Baskin, 2014). Larger seeds might withstand these adverse seasons better by allocating more seed resources to adaptations against cold temperatures (Canham et al., 1999), such as larger root systems, higher tissue density, apoplastic proteins and increased concentration of soluble sugars (Larcher, 2003). Annuals also show a larger and less predictable realized climatic niche compared with perennials, resulting in lower vulnerability to climatic changes (Broennimann et al., 2006; Hanspach et al., 2010; Boulangeat et al., 2011), again increasing the range of optimal temperature conditions at germination initiation. Altogether, this suggests that seedlings and juveniles from perennial plants are subject to stronger selective pressures with regard to temperature conditions than annuals, 
leading to a narrower range of temperatures for germination, and hence their optimal temperature for germination is influenced by seed size.

In Mediterranean climates, small-seeded species displayed higher base temperature values than large-seeded species. For Mediterranean annual species, Marañón and Grubb (1993) showed that small-seeded species had higher relative growth rate (RGR) than large-seeded species. Therefore, small-seeded species could delay germination with higher value of $T_{b}$ and accomplish the life cycle before drought. On the other hand, to complete their life cycle, large-seeded species with smaller RGR might germinate earlier by lower values of $T_{b}$ than small-seeded species.

In tropical climates, larger seeds are more weakly associated with higher germination temperatures than small seeds, which leads to slower germination for larger seeds compared with small seeds. Also, larger seeds have been shown to germinate more slowly than small-seeded species (Norden et al., 2009). Thus larger seeds slow germination by increasing the germination temperatures. Whereas the evolutionary constraints for slower germination of larger tropical tree seeds still need to be studied, previous work suggests a positive relationship between small seeds and high drought sensitivity (Daws et al., 2008). This suggests that smaller seeds select for faster development in order to escape unfavourable conditions.

\section{Base water potential and seed mass}

The base water potentials $\left(\Psi_{b}\right)$ of seed plants, and especially those from Mediterranean climate zones, show that $\Psi_{\mathrm{b}}$ decreases with seed mass. However, our analyses also highlight that lifespan critically influences this relationship, since only annual plants show a base water potential-seed mass relation in our data set.

A lower base water potential enables seed populations to germinate earlier and faster under dry conditions, as suggested by hydrotime models (Bradford, 2002). By germinating under drier conditions, seedlings from seeds with low base water potential are exposed to higher risks, since subsequent dry conditions or droughts might kill them (Daws et al., 2008; Mollard and Naeth, 2015). However, earlier germinating seedlings might also have higher fitness (Luis et al., 2008), because they produce more offspring and are larger or have higher survival rates at the end of the first growing season. Larger seeds are known to generate seedlings with higher survival rates in dry environments (Leishman and Westoby, 1994) and are even known to be associated with drier environment in local moisture gradients (Baker, 1972). This makes it clear that lower base water potentials enable large-seeded plants to exploit the advantages of the drought adaptation larger 
seeds confer on them. This is clear for the Mediterranean subset of our data, but probably applies to all climates with a marked dry season. The higher drought resistance of seedlings from larger seeds may be explained by their capacity to store more water or develop a more extensive root system, exploring larger volumes of soil to counterbalance lack of water (Leishman and Westoby, 1994; Saverimuttu and Westoby, 1996).

Models of evolution of seed banks suggest that large seeds act as a risk-reducing trait to withstand unpredictable drought and diminish the importance of other risk-reducing traits such as seed banks or dispersal (Venable and Brown, 1988; Philippi and Seger, 1989). High base water potential might also be a risk-reducing trait: it will lead to germination in much moister conditions and in this way prevent seedlings from being exposed to dry conditions in the beginning. In this sense base water potential and seed size can be seen as alternative risk-reducing traits. In contrast to annual plants, perennials rely on a longer lifespan and reproduction at greater age due to adaptations permitting their persistence through adverse seasons, such as storing organs, extensive root systems, dormant buds or extreme drought resistance (Larcher, 2003). These adaptations might further decrease the importance of adaptations at the seed stage due to selective interactions (Venable and Brown, 1988) and hence might lead to the observed picture of no relation between seed size and base water potential in perennials compared with a negative relation for annuals. Finally, since water conditions show a much higher inter-annual and spatial variability than temperature conditions, the resulting contrasting selective pressures for $\Psi_{b}$ may also contribute to the absence of phylogenetic signal in $\Psi_{\mathrm{b}}$. Moreover, our data suggest that the adaptive value of $\Psi_{\mathrm{b}}$ differs between annuals and perennials. Since the shift from perennials to annuals is a frequent convergent feature in many seed plant lineages, this additionally contributes to the evolutionary lability of $\Psi_{\mathrm{b}}$.

When we separate different biomes, the importance of the seed-size water-potential relationship varied among biomes and our analyses highlight its importance for the Mediterranean and nemoral climate. Moreover, data for tropical pioneer trees also suggest that high base water potential for germination avoids germination in dry environments even for these perennial plants, for which small seeds have higher base water potential (Daws et al., 2008). The negative relationship between seed size and base water potential for tropical pioneer trees is blurred in our data set by data from tropical plants from other habitats than pioneer trees, and we were thus not able to retrieve the same relationship.

Thermal aspects of germination niche, in contrast, have been proposed to be a close covariate of a plant climatic niche (Rosbakh and Poschlod, 2014), which is known to be highly phylogenetically conserved (Prinzing et al., 2001; Qian and Ricklefs, 2004; Schnitzler et al., 2012), as the result of historical-geographical constraints on niche evolution. Clearly, this reflects in our data set into 
higher $T_{b}$ for tropical compared with temperate species and between tropical and temperate seed plant clades (Supplementary Fig. S3). This gives support to the idea that $T_{b}$ evolved in response to similar selection pressures as the plant's climatic niches when comparing tropical with temperate species.

Base temperature turned out to be as phylogenetically conserved as seed size, implying that thermal aspects of regeneration by seeds might show slow adaptation and therefore be associated with high species replacement along gradients. Future studies might evaluate if changing the time for germination by modifying the level of dormancy can compensate and make seeds germinate in seasons or burial depths in accordance with their thermal germination requirements (Donohue et al., 2010; Saatkamp et al., 2011a). Water relations turned out to be more labile and seem to compensate for the evolutionary conservation of seed sizes; if this compensation mechanisms holds true, base water potential should increase in environments with decreasing moisture or increasing rainfall variability and be one of the traits increasing soil seed banks as a risk dispersion mechanism (Venable, 2007; Saatkamp et al., 2011b; Saatkamp et al., 2014; Huang et al., 2016).

\section{Supplementary material}

To view supplementary material for this article, please visit: https://doi.org/10.1017/S0960258517000083

\section{Acknowledgements}

We thank Michael Paul for revising the English of our manuscript. A.S., L.A. and F.A. were supported by the Région Provence-Alpes Côtes d'Azur, Gévoclé program, and Aix Marseille Université; A.S. and A.D. are funded by the European Union ENPI CBC-MED GREAT-MED program. The authors declare no competing interests. 


\section{References}

Agrawal, A.A., Johnson, M.T.J., Hastings, A.P. and Maron, J.L. (2013) A field experiment demonstrating plant life-history evolution and its eco-evolutionary feedback to seed predator populations. American Naturalist 181, 3545.

Aizen, M.A. and Woodcock, H. (1996) Effects of acorn size on seedling survival and growth in Quercus rubra following simulated spring freeze. Canadian Journal of Botany 74, 308314.

Allen, P.S., Meyer, S.E. and Khan, M.A. (2000) Hydrothermal time as a tool in comparative germination studies. In Black, M., Bradford, K.J. and Vázquez-Ramos, J. (eds), Seed Biology: Advances and applications, pp. 401-410. Proceedings of the Sixth International Workshop on Seeds, Merida, Mexico. Wallingford, UK: CABI Publishing.

Bair, N.B., Meyer, S.E. and Allen, P.S. (2006) A hydrothermal after-ripening time model for seed dormancy loss in Bromus tectorum L. Seed Science Research 16, 1728.

Baker, H.G. (1972) Seed weight in relation to environmental conditions in California. Ecology 53, 9971010.

Baskin, C.C. and Baskin, J.M. (2014) Seeds: Ecology, Biogeography and Evolution of Dormancy and Germination. Burlington: Academic Press.

Baskin, J.M., Baskin, C.C. and Xiaojie, L. (2000) Taxonomy, anatomy and evolution of physical dormancy in seeds. Plant Species Biology 15, 139152.

Batlla, D. and Benech-Arnold, R.L. (2003) A quantitative analysis of dormancy loss dynamics in Polygonum avicu lare L. seeds: development of a thermal time model based on changes in seed population thermal parameters. Seed Science Research 13, 5568.

Boulangeat, I., Lavergne, S., Van Es, J., Garraud, L. and Thuiller, W. (2011) Niche breadth, rarity and ecological characteristics within a regional flora spanning large environmental gradients. Journal of Biogeography 39, 204214.

Bradford, K.J. (2002) Applications of hydrothermal time to quantifying and modeling seed germination and dormancy. Weed Science 50, 248260.

Broennimann, O., Thuiller, W., Hughes, G., Midgley, G.F., Alkemade, J.M.R. and Guisan, A. (2006) Do geographic distribution, niche property and life form explain plants' vulnerability to global change? Global Change Biology 12, 10791093. 
Bykova, O., Chuine, I., Morin, X. and Higgins, S.I. (2012) Temperature dependence of the reproduction niche and its relevance for plant species distributions. Journal of Biogeography 39, 21912200.

Canham, C.D., Kobe, R.K., Latty, E.F. and Chazdon, R.L. (1999) Interspecific and intraspecific variation in tree seedling survival: effects of allocation to roots versus carbohydrate reserves. Oecologia 121, 111.

Chave, J., Coomes, D., Jansen, S., Lewis, S.L., Swenson, N.G. and Zanne, A.E. (2009) Towards a worldwide wood economics spectrum. Ecology Letters 12, 351 c366.

Chuine, I. (2010) Why does phenology drive species distribution? Philosophical Transactions of the Royal Society B: Biological Sciences 365, 31493149.

Daniel, R.M. and Danson, M.J. (2010) A new understanding of how temperature affects the catalytic activity of enzymes. Trends in Biochemical Sciences 35, 584591.

Daws, M.I., Crabtree, L.M., Dalling, J.W., Mullins, C.E. and Burslem, D.F.R.P. (2008) Germination responses to water potential in neotropical pioneers suggest large-seeded species take more risks. Annals of Botany 102, 945951.

Donoghue, M.J. and Edwards, E.J. (2014) Biome shifts and niche evolution in plants. Annual Review of Ecology, Evolutio, and Systematics 45, 547572.

Donohue, K. (2002) Germination timing influences natural selection on life-history characters in Arabidopsis thaliana. Ecology 83, 10061016.

Donohue, K., Dorn, L., Griffith, C., Kim, E., Aguilera, A., Polisetty, C.R. and Schmitt, J. (2005) Environmental and genetic influences on the germination of Arabidopsis thaliana in the field. Evolution 59, 740757.

Donohue, K., Rubio de Casas, R., Burghardt, L., Kovach, K. and Willis, C.G. (2010) Germination, postgermination adaptation, and species ecological ranges. Annual Reviews of Ecology, Evolution and Systematics 41, 293319.

Durka, W. and Michalski, S.G. (2012) Daphne: a dated phylogeny of a large European flora for phylogenetically informed ecological analyses. Ecology 93, 22972297. 
Dürr, C., Dickie, J.B., Yang, X.Y. and Pritchard, H.W. (2015) Ranges of critical temperature and water potential values for the germination of species worldwide: contribution to a seed trait database. Agricultural and forest meteorology 200, 222232.

Evans, M.E.K., Hearn, D.J., Hahn, W.J., Spangle, J.M. and Venable, D.L. (2005) Climate and lifehistory evolution in evening primroses (Oenothera, Onagraceae): a phylogenetic comparative analysis. Evolution 59, 19141927.

Felsenstein, J. (1985) Phylogenies and the comparative method. American Naturalist 125, 115.

Finch-Savage, W.E. and Leubner-Metzger, G. (2006) Seed dormancy and the control of germination. New Phytologist 171, 501523.

Forbis, T.A., Floyd, S.K. and Queiroz, A.D. (2002) The evolution of embryo size in angiosperms and other seed plants: implications for the evolution of seed dormancy. Evolution 56, 21122125.

Foster, S. and Janson, C.H. (1985) The relationship between seed size and establishment conditions in tropical woody plants. Ecology 66, 773780.

Freckleton, R.P., Harvey, P.H. and Pagel, M. (2002) Phylogenetic analysis and comparative data: a test and review of evidence. American Naturalist 160, 712726.

Gallagher, R.V., Beaumont, L.J., Hughes, L. and Leishman, M.R. (2010) Evidence for climatic niche and biome shifts between native and novel ranges in plant species introduced to Australia. Journal of Ecology 98, 790799.

García-Baquero, G., Silvertown, J., Gowing, D.J. and Valle, C.J. (2015) Dissecting the hydrological niche: soil moisture, space and lifespan. Journal of Vegetation Science 27, 219226.

Garnier, E. (1992) Growth analysis of congeneric annual and perennial grass species. Journal of Ecology 80, 665675.

Grafen, A. (1989) The phylogenetic regression. Philosophical Transactions of the Royal Society Series B 326, 119157.

Grubb, P.J. (1977) Maintenance of species-richness in plant communities: the importance of the regeneration niche. Biological Reviews of the Cambridge Philosophical Society 52, 107145. 
Hanspach, J., Kühn, I., Pompe, S. and Klotz, S. (2010) Predictive performance of plant species distribution models depends on species traits. Perspectives in Plant Ecology, Evolution and Systematics 12, 219225.

Harper, J.L. (1977) Population Biology of Plants. London: Academic Press.

Harper, J.L., Williams, J.T. and Sagar, G.R. (1965) The behaviour of seeds in soil: I. The heterogeneity of soil surfaces and its role in determining the establishment of plants from seed. Journal of Ecology 53, 273286.

Holdsworth, M.J., Finch-Savage, W.E., Grappin, P. and Job, D. (2008) Post-genomics dissection of seed dormancy and germination. Trends in Plant Science 13, 713.

Holt, G. and Chesson, P. (2014) Variation in moisture duration as a driver of coexistence by the storage effect in desert annual plants. Theoretical Population Biology 92, 3650.

Huang, Z., Liu, S., Bradford, K.J., Huxman, T.E. and Venable, D.L. (2016) The contribution of germination functional traits to population dynamics of a desert plant community. Ecology 97, 250 261.

Jiménez-Alfaro, B., Silveira, F.A., Fidelis, A., Poschlod, P. and Commander, L.E. (2016) Seed germination traits can contribute better to plant community ecology. Journal of Vegetation Science 27, 637645 .

Jump, A.S. and Penuelas, J. (2005) Running to stand still: adaptation and the response of plants to rapid climate change. Ecology Letters 8, 10101020.

Kleyer, M., Bekker, R.M., Knevel, I.C., Bakker, J.P., Thompson, K., Sonnenschein, M., Poschlod, P., van Groenendael, J.M., Klimeš, L., Klimešová, J., Klotz, S., Rusch, G.M., Hermy, M., Adriaens, D., Boedeltje, G., Bossuyt, B., Dannemann, A., Endels, P., Götzenberger, L., Hodgson, J.G., Jackel, A.K., Kühn, I., Kunzmann, D., Ozinga, W.A., Römermann, C., Stadler, M., Schlegelmilch, J., Steendam, H.J., Tackenberg, O., Wilmann, B., Cornelissen, J.H.C., Eriksson, O., Garnier, E. and Peco, B. (2008) The LEDA Traitbase: a database of life-history traits of the Northwest European flora. Journal of Ecology 96, 12661274.

Köchy, M. and Tielbörger, K. (2007) Hydrothermal time model of germination: parameters for 36 Mediterranean annual species based on a simplified approach. Basic and Applied Ecology 8, 171 182. 
Kruk, B., Insausti, P., Razul, A. and Benech-Arnold, R.L. (2006) Light and thermal environments as modified by a wheat crop: effects on weed seed germination. Journal of Applied Ecology 43, 227 236.

Larcher, W. (2003) Physiological Plant Ecology: Ecophysiology and Stress Physiology of Functional Groups. Berlin, Heidelberg: Springer Verlag.

Leishman, M.R. and Westoby, M. (1994) The role of seed size in seedling establishment in dry soil conditions experimental evidence from semi-arid species. Journal of Ecology 82, 249258.

Leishman, M.R., Wright, I.J., Moles, A.T. and Westoby, M. (2000) The evolutionary ecology of seed size. In Fenner, M. (ed), Seeds The Ecology of Regeneration in Plant Communities, pp. 31 57. Wallingford, UK: CABI Publishing.

Lloret, F., Casanovas, C. and Penuelas, J. (1999) Seedling survival of Mediterranean shrubland species in relation to root:shoot ratio, seed size and water and nitrogen use. Functional Ecology $13,210216$.

Lodge, G.M. and Whalley, R.D.B. (1981) Establishment of warm- and cool-season native perennial grasses on the north-west slopes of New South Wales. I. Dormancy and germination. Australian Journal of Botany 29, 111119.

Losos, J.B. (2008) Phylogenetic niche conservatism, phylogenetic signal and the relationship between phylogenetic relatedness and ecological similarity among species. Ecology Letters 11, 9951003.

Luis, M.D., Verdù, M. and Raventós, J. (2008) Early to rise makes a plant healthy, wealthy, and wise. Ecology 89, 30613071.

Marañón, T. and Grubb, P.J. (1993) Physiological basis and ecological significance of the seed size and relative growth rate relationship in Mediterranean annuals. Functional Ecology 7, 591599.

Mazer, S.J. (1989) Ecological, taxonomic, and life history correlates of seed mass among Indiana dune angiosperms. Ecological Monographs 59, 153175.

McGill, B.J., Enquist, B.J., Weiher, E. and Westoby, M. (2006) Rebuilding community ecology from functional traits. Trends in Ecology and Evolution 21, 178185.

Metcalfe, D.J. and Grubb, P.J. (1995) Seed mass and light requirements for regeneration in Southeast Asian rain forest. Canadian Journal of Botany 73, 817826. 
Metz, J., Liancourt, P., Kigel, J., Harel, D., Sternberg, M. and Tielbörger, K. (2010) Plant survival in relation to seed size along environmental gradients: a long-term study from semi-arid and Mediterranean annual plant communities. Journal of Ecology 98, 697704.

Moles, A.T., Ackerly, D.D., Tweddle, J.C., Dickie, J.B., Smith, R., Leishman, M.R., Mayfield, M.M., Pitman, A., Wood, J.T. and Westoby, M. (2007) Global patterns in seed size. Global Ecology and Biogeography 16, 109116.

Moles, A.T., Ackerly, D.D., Webb, C.O., Tweddle, J.C., Dickie, J.B., Pitman, A.J. and Westoby, M. (2005) Factors that shape seed mass evolution. Proceedings of the National Academy of Sciences, USA 102, 1054010540.

Moles, A.T., Falster, D.S., Leishman, M.R. and Westoby, M. (2004) Small-seeded species produce more seeds per square metre of canopy per year, but not per individual per lifetime. Journal of Ecology 92, 384396.

Moles, A.T. and Westoby, M. (2004) Seedling survival and seed size: a synthesis of the literature. Journal of Ecology 92, 372383.

Mollard, F.P.O. and Naeth, M.A. (2015) Germination sensitivities to water potential among coexisting C3 and C4 grasses of cool semi-arid prairie grasslands. Plant Biology 17, 583587.

Morin, X., Augspurger, C. and Chuine, I. (2007) Process-based modeling of species' distributions: what limits temperature tree species' range boundaries? Ecology 88, 22802291.

Münkemüller, T., Lavergne, S., Bzeznik, B., Dray, S., Jombart, T., Schiffers, K. and Thuiller, W. (2012) How to measure and test phylogenetic signal. Methods in Ecology and Evolution 3, 743 756.

Norden, N., Daws, M.I., Antoine, C., Gonzalez, M.A., Garwood, N.C. and Chave, J. (2009) The relationship between seed mass and mean time to germination for 1037 tree species across five tropical forests. Functional Ecology 23, 203210.

Olano, J.M., Caballero, I. and Escudero, A. (2012) Soil seed bank recovery occurs more rapidly than expected in semi-arid Mediterranean gypsum vegetation. Annals of Botany 109, 299307.

Orme, D. (2013) The caper package: comparative analysis of phylogenetics and evolution in R. R package, version 5 .

Pagel, M. (1999) Inferring the historical patterns of biological evolution. Nature 401, 877884. 
Parmesan, C., Gaines, S., Gonzalez, L., Kaufman, D.M., Kingsolver, J., Townsend Peterson, A. and Sagarin, R. (2005) Empirical perspectives on species borders: from traditional biogeography to global change. Oikos 108, 5875.

Philippi, T. and Seger, J. (1989) Hedging one's evolutionary bets, revisited. Trends in Ecology and Evolution 4, 4144.

Poorter, H. and Nagel, O. (2000) The role of biomass allocation in the growth response of plants to different levels of light, $\mathrm{CO}_{2}$, nutrients and water: a quantitative review. Functional Plant Biology 27, 11911191.

Poorter, L. (2007) Are species adapted to their regeneration niche, adult niche, or both? The American Naturalist 169, 433442.

Primack, R.B. (1979) Reproductive effort in annual and perennial species of Plantago (Plantaginaceae). The American Naturalist 114, 5162.

Prinzing, A., Durka, W., Klotz, S. and Brandl, R. (2001) The niche of higher plants: evidence for phylogenetic conservatism. Proceedings of the Royal Society B: Biological Sciences 268, 2383 2389.

Qian, H. and Ricklefs, R.E. (2004) Geographical distribution and ecological conservatism of disjunct genera of vascular plants in eastern Asia and eastern North America. Journal of Ecology 92, 253265.

R Core Team (2014) R: a language and environment for statistical computing. Vienna, Austria: R Foundation for Statistical Computing.

Revell, L.J. (2010) Phylogenetic signal and linear regression on species data. Methods in Ecology and Evolution 1, 319-329.

Roche, P., Diaz-Burlinson, N. and Gachet, S. (2004) Congruency analysis of species ranking based on leaf traits: which traits are the more reliable? Plant Ecology 174, 3748.

Rosbakh, S. and Poschlod, P. (2014) Initial temperature of seed germination as related to species occurrence along a temperature gradient. Functional Ecology 29, 514.

Roumet, C., Urcelay, C. and Diaz, S. (2006) Suites of root traits differ between annual and perennial species growing in the field. New Phytologist 170, 357368. 
Royal Botanic Gardens, Kew (2014) Seed information data-base version 7.1.

Rustad, L., Campbell, J., Marion, G., Norby, R., Mitchell, M., Hartley, A., Cornelissen, J. and Gurevitch, J. (2001) A meta-analysis of the response of soil respiration, net nitrogen mineralization, and aboveground plant growth to experimental ecosystem warming. Oecologia 126, 543562.

Saatkamp, A., Affre, L., Baumberger, T., Dumas, P.J., Gasmi, A., Gachet, S. and Arène, F. (2011a) Soil depth detection by seeds and diurnally fluctuating temperatures: different dynamics in 10 annual plants. Plant and Soil 349, 331340.

Saatkamp, A., Affre, L., Dutoit, T. and Poschlod, P. (2011b) Germination traits explain soil seed persistence across species: the case of Mediterranean annual plants in cereal fields. Annals of Botany 107, 415.

Saatkamp, A., Poschlod, P. and Venable, D.L. (2014) The functional role of soil seed banks in natural communities. In Gallagher, R.S. (ed), SeedsThe Ecology of Regeneration in Plant Communities, pp. 263 294. Wallingford, UK: CABI Publishing.

Sack, L., Scoffoni, C., John, G.P., Poorter, H., Mason, C.M., Mendez-Alonzo, R. and Donovan, L.A. (2013) How do leaf veins influence the worldwide leaf economic spectrum? Review and synthesis. Journal of Experimental Botany 64, 40534080.

Salisbury, E.J. (1942) The Reproductive Capacity of Plants. London: Bell.

Sarukhan, J. and Harper, J.L. (1973) Studies on plant demography: Ranunculus repens L., R. bulbosus L. and R. acris L.: I. Population flux and survivorship. Journal of Ecology 61, 675716.

Saverimuttu, T. and Westoby, M. (1996) Seedling longevity under deep shade in relation to seed size. Journal of Ecology 84, 681689.

Schmid, M., Davison, T.S., Henz, S.R., Pape, U.J., Demar, M., Vingron, M., Schölkopf, B., Weigel, D. and Lohmann, J.U. (2005) A gene expression map of Arabidopsis thaliana development. Nature Genetics 37, 501506.

Schnitzler, J., Graham, C.H., Dormann, C.F., Schiffers, K. and Peter Linder, H. (2012) Climatic niche evolution and species diversification in the Cape flora, South Africa. Journal of Biogeography 39, 22012211.

Silvertown, J., Araya, Y. and Gowing, D. (2015) Hydrological niches in terrestrial plant communities: a review. Journal of Ecology 103, 93108. 
Steinmaus, S.J., Prather, T.S. and Holt, J.S. (2000) Estimation of base temperatures for nine weed species. Journal of Experimental Botany 51, 275275.

Thomas, H. (1990) Osmotic adjustment in Lolium perenne; its heritability and the nature of solute accumulation. Annals of Botany 66, 521530.

Thompson, P.A. (1970a) Changes in germination responses of Silene secundiflora in relation to the climate of its habitat. Physiologia Plantarum 23, 739746.

Thompson, P.A. (1970b) Germination of species of Caryophyllaceae in relation to their geographical distribution in Europe. Annals of Botany 34, 427449.

Trudgill, D.L., Honek, A., Li, D. and Straalen, N.M. (2005) Thermal time-concepts and utility. Annals of Applied Biology 146, 114.

Tutin, T.G., Heywood, V.H., Valentine, D.H., Walters, S.M. and Webb, D.A. (1964) Flora Europaea. Cambridge, UK: Cambridge University Press.

Venable, D.L. (2007) Bet hedging in a guild of desert annuals. Ecology 88, 10861090.

Venable, D.L. and Brown, J.S. (1988) The selective inter-action of dispersal, dormancy and seed size as adaptations for reducing risks in variable environments. American Naturalist 131, 360384.

Wright, I.J., Reich, P.B., Westoby, M., Ackerly, D.D., Baruch, Z., Bongers, F., Cavender-Bares, J., Chapin, T., Cornelissen, J.H.C., Diemer, M., Flexas, J., Garnier, E., Groom, P.K., Gulias, J., Hikosaka, K., Lamont, B.B., Lee, T., Lee, W., Lusk, C., Midgley, J.J., Navas, M.L., Niinemets, U., Oleksyn, J., Osada, N., Poorter, H., Poot, P., Prior, L., Pyankov, V.I., Roumet, C., Thomas, S.C., Tjoelker, M.G., Veneklaas, E.J. and Villar, R. (2004) The worldwide leaf economics spectrum. Nature 428, 821827. 